\title{
SIMULATION AND ANALYSIS OF QUEUES IN BANKS: A CASE STUDY OF AN AGENCY IN THE SOUTHERN STATE OF RIO DE JANEIRO
}

\author{
Tulio Cremonini Entringer \\ Universidade Estadual do Norte Fluminense Darcy Ribeiro, Brazil \\ E-mail: tulio_entringer@hotmail.com
}

Submission: 6/7/2019

Revision: 9/18/2019

Accept: 9/25/2019

\section{ABSTRACT}

An in-depth study of wait times in queues has become a factor of the banks' full interest for service improvements and reduced operating costs. When the demand is greater than the capacity offered the queue is formed, that is, queuing system is any process where a distinct group waits for a service. When there is adequate management, customer waiting time can be minimized, resulting in customer satisfaction and hence higher profitability. In view of this, the present work proposes a study of the flow of clients in an agency banking in the southern state of Rio de Janeiro. This work uses the qualitative and quantitative approach. The research is classified as descriptive, explanatory, bibliographical and case study. This work also presents the main concepts about simulation, modeling, specifically, in the Arena software, and describes the method of how the data were obtained for the construction of the model. The model simulates the capacity rate, number of customers in the queue, time of service and waiting time at which the customer can be subject at the agency banking. With such a study, we can analyze the behavior of queues in the system and thus propose improvements in order to guarantee the best scenario for both organization and customer satisfaction.

Keywords: Simulation; Queuing Theory; Banking service; Banking agency. 
ISSN: $2236-269 X$

DOI: 10.14807/ijmp.v11i3.1074

\section{INTRODUCTION}

The service sector has great importance in the Brazilian economy, being considered a promise for the development of the country, and one of the greatest generators of jobs. According to Fiebig AND Freitas (2011), this sector has some peculiarities that must be taken into account, which are the intangibility: services can not be perceived by touch, nor smells and ears, before the purchase can be made or the service requested; inseparability: it is not possible to separate the service from the provider, and its production in large quantities may not be easy; variability: the quality of the services depends on the provider, without which the clients can intervene, participate and help; and perishability: services can not be stored, resold or returned to the provider. The same author reports that these factors represent one more obstacle to follow in this sector.

Within the service sector, since the Middle Ages there are reports of banking services, but it was in the seventeenth century that began to act more formally with the issuance of paper money. Agencies banking generally (private or public) are financial institutions that offer credit and payment services to society, work with money deposited by their savers, providing credit to those in need, being individuals or legal entities, charging interest on borrowers by making the money circulate, thereby helping in the maintenance of the economy (CAMARGO, 2009).

With increased competition in the banking sector due to mergers and growth in the marketplace like credit shops, banks have begun to get closer to their customers so they have no impact on profits. With the advancement of technology there has been a contribution to changes in service with a greater share of digital resources, where it is possible to do almost all transactions from home, by telephone or computer applications. As a result, more and more banks invest in these technologies to improve customer service in order to increase loyalty and satisfaction with quality service, since keeping a customer is more profitable than winning new ones (ZACHARIAS; FIGUEIREDO; ALMEIDA, 2008).

As in the banking sector the products are similar, what counts are the quality of service and the services provided. As a result, the service in the agencies has a level of demand with an increasingly high quality service, taking into account customer satisfaction.

In this sense, the improvement of the processes of a banking company is of extreme importance for the competitiveness, reliability and profitability of the bank and the greater satisfaction of the clients. When the management tools are used correctly, possible causes and 
DOI: 10.14807/ijmp.v11i3.1074

solutions of the problem can be perceived with some speed and become a factor of total interest of the banks for improvements of their services (NUNES; NOGUEIRA, 2013).

When examining a problem to propose changes or adaptations of the method already used, several ways of evaluating the alternatives can be used. A simulation model fits perfectly in context. With the use of simulation software, one can have an overview of the problem and seek ways of improvement with a reduction of time and relevant costs (NUNES; NOGUEIRA, 2013).

In this context, this paper studies the behavior of the queues of a branch office in the southern state of Rio de Janeiro, emphasizing evaluating the operational performance of the system in operation and efficiently dimensioning new systems, providing possible improvements.

\subsection{Practical Motivating Situation}

For Labadessa and Oliveira (2012), the customer is always in the first place, this is the basis of the philosophy of quality. The quality care must be performed every day in any company, regardless of the service or care provided by it, thus conserving its current customers and conquering new ones. Good service is paramount for the growth of the company and its maintenance.

The first section presents the contextualization and the objective and the practical motivating situation of this research. The second section presents an approach to queuing theory, especially in banking agencies. The third section presents the research methods, which included the description of agency banking of this study and the simulation model. The following section presents the analysis of results, which include the authors and journals that published the most in the study area (publications analysis); the main approaches of papers related to software quality (approach analysis); and the most cited papers in the database searched, taking into account the impact factor of the journal in which the work was published. Finally, the last section presents the findings of the study.

\section{QUEUING THEORY}

According to Hillier and Lieberman (2010), queuing training is a phenomenon that occurs when demand becomes greater than the ability to deliver a service over a given period. For example, if the number of servers is less than necessary at a restaurant during lunch time, the customer may end up waiting longer than he or she is willing, resulting in dissatisfaction or even discontinuance of service usage. 
DOI: 10.14807/ijmp.v11i3.1074

However, the analysis of the opposite case is also fundamental. If the number of servers allocated is greater than necessary, the cost to maintain them becomes high. For these analyzes, it is necessary to take into account the conditions of the establishment, such as office hours, number of consumers seeking the service and peak hours.

In this context, the study of waiting in all its most diverse forms arises. Queuing theory, as it is known, uses queue models to represent different cases and aims to balance the costs between offering services and the costs of delays suffered by users of the system (ARENALES et al., 2007). Moreira (2007) says that this theory is a body of mathematical knowledge, applied to the phenomena of rows. Its main objective is to develop mathematical models that allow predicting the behavior of service delivery systems (MARINS, 2011).

For Guedes and Araújo (2013), queuing theory aims to identify, through mathematical analysis, the queuing measurement, providing for the organization of waiting, aiming at customer satisfaction and profitability of the company, thus having a satisfactory balance for both.

There is a diversity of applicability over queuing theory, as shown in Table 1.

Table 1: Applicability of the queuing theory.

\begin{tabular}{|l|l|}
\hline \multicolumn{1}{|c|}{ Author } & \multicolumn{1}{c|}{ Applied Sector } \\
\hline Bouzada (2009) & Call center \\
\hline Doile (2010) & Supermarket \\
\hline Camelo (2010) & Port terminal \\
\hline Pinto (2011) & Bank \\
\hline Santos and Lira (2017) & Hospital \\
\hline Junior et al. (2017) & Metallurgical industry \\
\hline
\end{tabular}

A queuing system is identified as any and all processes in which people arrive to receive a service they are waiting for (FOGLIATTI; MATTOS, 2007). It basically consists of a source, where the customers arrive, the queue, where they must wait and the service mechanism, where customers or products do what is to be done and leave the system. It is important to remember that the queuing system is formed by both who is being served and who is waiting for the service. In this way, the basic process of queuing is: entering customers by a source, waiting in queue, attending and leaving customers attended (Figure 1). 
DOI: 10.14807/ijmp.v11i3.1074

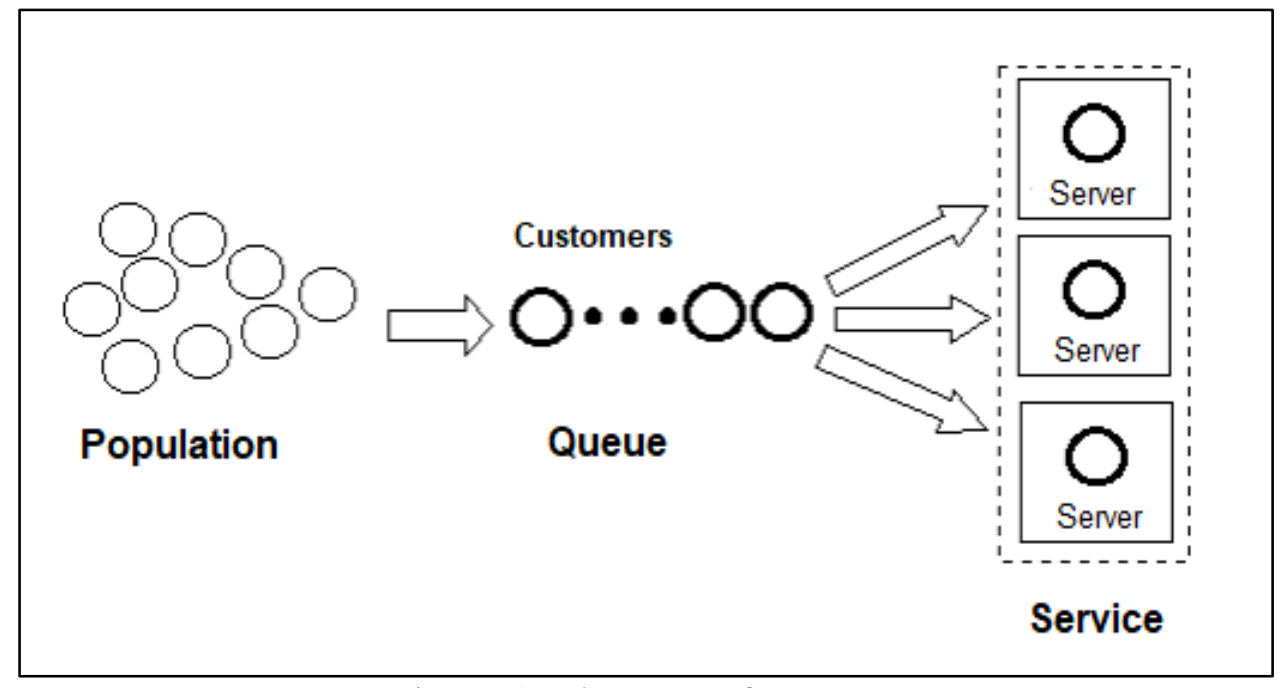

Figure 1: Elements of a queue. Source: Prado (2009).

Due to the possibilities of the arrival process of the clients in a given establishment, there is a need to organize queues to improve and facilitate the service, because if there is no organization, several problems arise which make service difficult (SCHEMENNER, 1999).

For Martins el al. (2017), the sequence of the service is what the next customer will be served. The queue can follow two models being FIFO (First In - First Out) the first to arrive is the first to be attended, that is, the first that enters the system and the first to leave it; LIFO (Last In-First Out), the last one to arrive is the first to be attended, determining priority, the customer with priority is the first to be attended.

According to Andrade (2009), the need to study queuing theory would be to promote modifications that improve the performance of a service, because when there is a great demand for a service or service system, they cause large queues, resulting in customer dissatisfaction ; or when they do not feel this demand, the system stays for a long period of time stopped, bringing losses. In both situations there would be a recommendation for experimental changes, almost always unfeasible for expenses.

With a system that can demonstrate the possible behavior of the queue, it would be easier to choose the most viable changes, thus demonstrating the form of attendance, customer arrival, system structure, and queuing discipline.

Within the queuing theory, it is inevitable not to think about the long waits encountered in bank branches. Given this, the next topic will portray this situation, where long queues generate customer dissatisfaction, since the application of queuing theory can bring an 
DOI: 10.14807/ijmp.v11i3.1074

improvement in the management of customer service leading to customer satisfaction and thus generating more business for the banking system .

\subsection{Queues in Agencies Banking}

In one day of service, the concentration of clients does not follow a continuous order, having moments with the flow greater or less at certain different times. These queues are with oscillations to establish a reasonable time of service, since maintaining the demand compatible with the need is fundamental in service in the banking branches (MARQUES, 2012).

According to Fernandes and Santos (2008), with a poor customer service, the client may have several attitudes, such as not going back to the store, switching to a product or brand, complaining to salespeople or even doing negative marketing, with people nearby.

With the highly competitive banking market, these situations demand great attention, since having a loyal client over a long term is fundamental (FERNANDES; SANTOS, 2008). In this context, the poor quality of banking service is related to the expectation of the service provided, the banks can not meet the clients' needs, leaving them dissatisfied with the services offered (ZENOTE, 2007).

Second, Lovelock and Wirtz (2006), given these concepts the result of a service provided depends on who executes it. In the case of bank agencies, it is the employees who work in the agency who are responsible for this. This group of employees performs the service with personal characteristics influencing the final result of the service activity, thus reflecting the image of the company.

\section{METHODOLOGICAL RESOURCES}

For this study, the systematics proposed by Vergara (2016), which qualifies the classification of the research in two aspects: as to the ends and the means, was taken as basis.

This work uses the qualitative and quantitative approach. The research is classified as regards the purposes as descriptive and explanatory and as to the means such as bibliographical and case study.

Descriptive, because it presents the main concepts regarding simulation, modeling, specifically, in the Arena software. Explanatory because it describes the method of how the data were obtained for the construction of the model. 
DOI: 10.14807/ijmp.v11i3.1074

As for the means, the research is classified as a bibliographical of the virtual type, since the research was carried out through literary revision, about modeling and simulation, and as a case study, since the theoretical reference was applied in a company.

\subsection{Description of Agency Banking}

This paper studies the behavior of the queues of a branch office in the southern state of Rio de Janeiro.

The agency chosen for this study has the services of hand boxes - conventional, preferential and other assistance, such as management - and ATMs - self-service - with single independent queues, characterizing, in this way, a typical agency with the services now in studied. For analysis, only the behavior of conventional cartons will be studied.

The layout of the bank branch is shown in Figure 2.

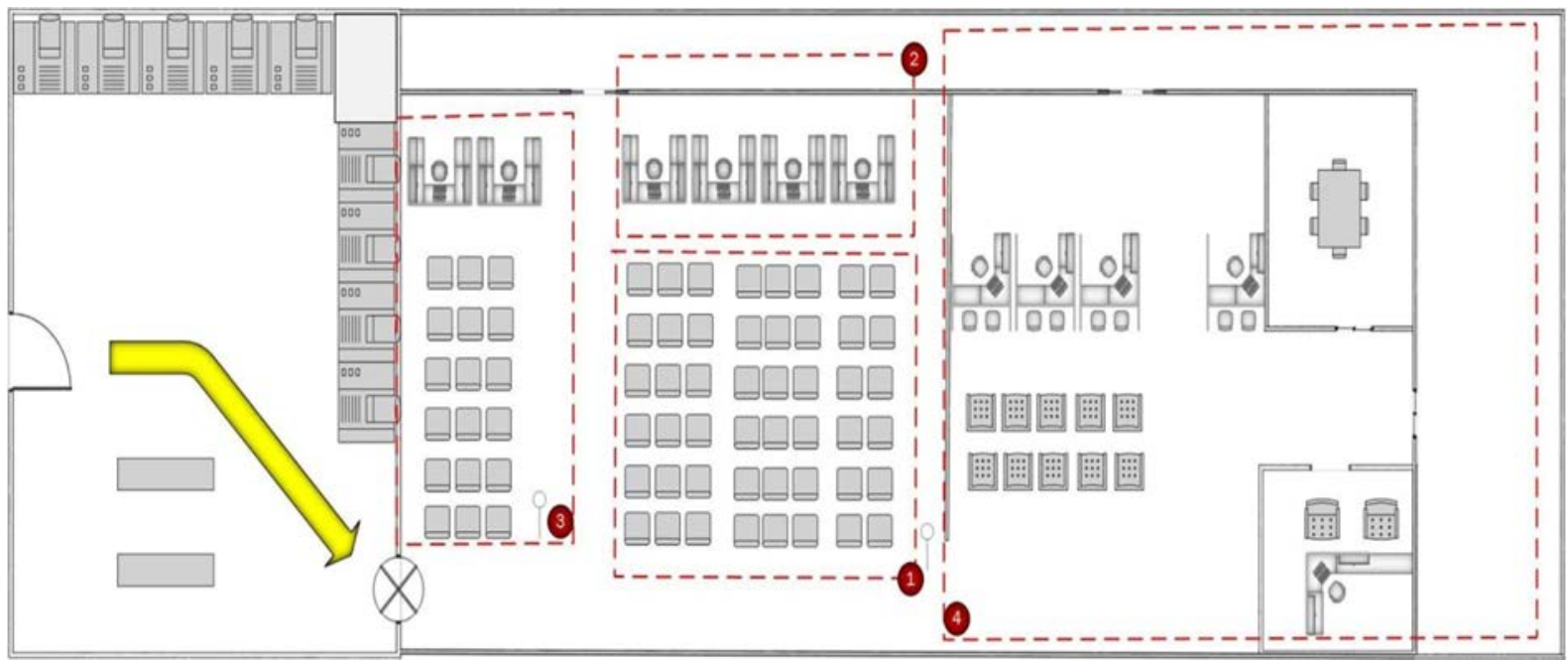

Figure 2: Layout of the bank branch.

The priority service works separately, as shown in Figure 2 (zone 3), and is not the object of study of this work. One can observe the entrance of the agency and soon after the ATMs. After the revolving door are the conventional calls (zone 2), where the clients take the passwords and wait for the service (zone 1). In the agency, the system of queues is by password, that is, the client arrives takes the password, waits in the chairs destined for that purpose, and is answered on a first-come, first-served basis. And, finally, there is a specific area for other types of services (zone 4), such as requesting credit cards, requesting loans, contacting management, among others.

Regarding non-priority customer service (conventional), it works from eleven o'clock until sixteen o'clock. Being that it works with three employees in the first four hours and with 
ISSN: 2236-269X

DOI: 10.14807/ijmp.v11i3.1074

four employees in the last hour, following the policy adopted by the organization during the lunch period of the employees, as shown in Table 2. In summary:

- 3 banking service desks working from 11:00 a.m. to 3:00 p.m.; and

- 4 banking service desks working from 3:00 p.m. to 4:00 p.m.

Table 2: Employee schedule.

\begin{tabular}{|c|c|c|c|c|}
\hline Schedule & \multicolumn{4}{|c|}{ Service Desk } \\
\hline 11:00 a.m. - 12:00 p.m. & Employee A & Employee B & Employee C & \\
\hline 12:00 p.m. - 01:00 p.m. & & Employee B & Employee C & Employee D \\
\hline 01:00 p.m. - 02:00 p.m. & Employee A & & Employee C & Employee D \\
\hline 02:00 p.m. - 03:00 p.m. & Employee A & Employee B & & Employee D \\
\hline 03:00 p.m. - 04:00 p.m. & Employee A & Employee B & Employee C & Employee D \\
\hline
\end{tabular}

\subsection{Description of the simulation model}

The modeling of a system depends on the purpose and complexity of the system under investigation, and the model can be of the mathematical, descriptive, statistical and inputoutput type (FREITAS FILHO, 2008). Most simulation models are input-output type, that is, iterative models where input data is provided and specific responses are obtained (FREITAS FILHO, 2008). Thus, according to Chwif (2006), the input variables required to execute the model are:

- $\quad$ Service time;

- Interval between successive arrivals.

The conceptual model was elaborated using the logical elements proposed by (LEAL; ALMEIDA; MONTEVECHI, 2008). The translation of the conceptual model of the system to the computer simulation model was performed using the software Arena ${ }^{\circledR} 12$, student version (KELTON; SADOWSKI; STURROCK, 2007).

The data collected refer to the first two weeks of August 2018 and are provided for academic purposes by the agency's management.

Figures 3 to 9 show the arrival times of the clients in the agency for the conventional attendances, during the working day (11:00 a.m. - 04:00 p.m.) during the days under study.

As mentioned before, the software used was Arena, student version, due to its ease of use, because the program allows, besides the construction of the simulation model, analyze the input data (through the Input Analyzer module), analyze the results (through the Output Analyzer) and visualize the simulation (through the Arena Viewer) (PRADO, 1999). 
INDEPENDENT JOURNAL OF MANAGEMENT \& PRODUCTION (IJM\&P)

http://www.ijmp.jor.br

v. 11, n. 3, May-June 2020

ISSN: 2236-269X

DOI: 10.14807/ijmp.v11i3.1074

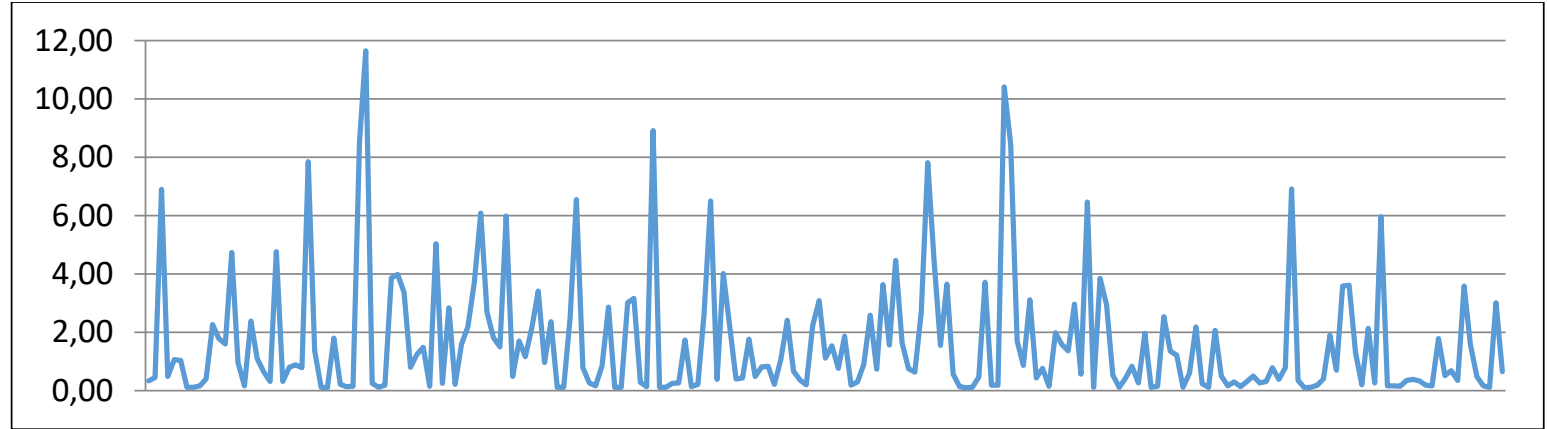

Figure 3: Customer arrival time in minutes on August 11, 2018.

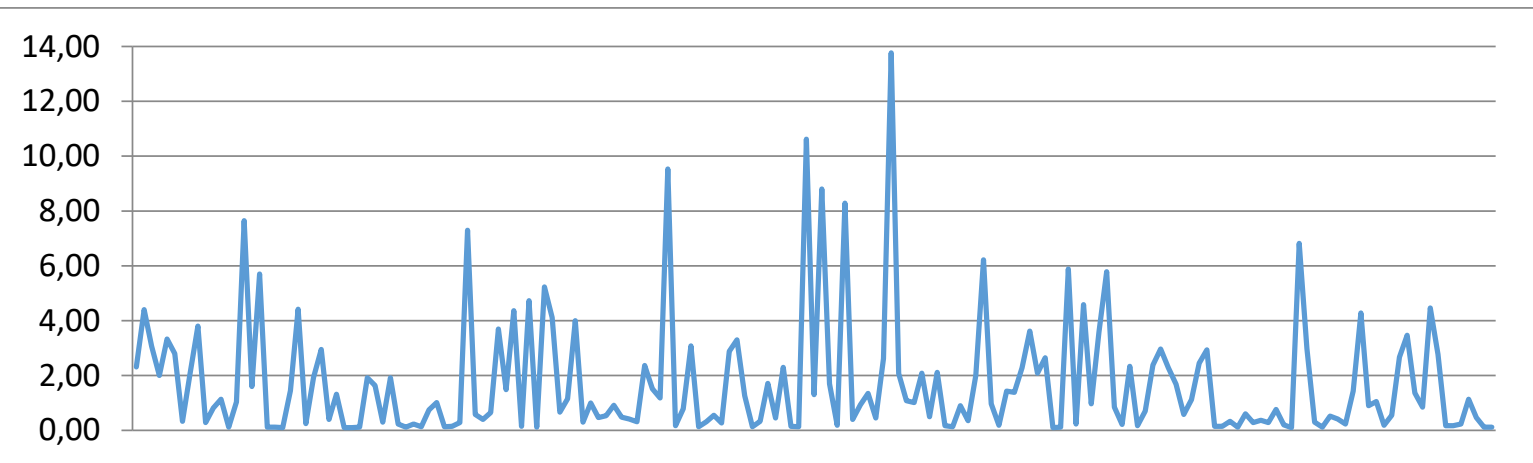

Figure 4: Customer arrival time in minutes on August 12, 2018.

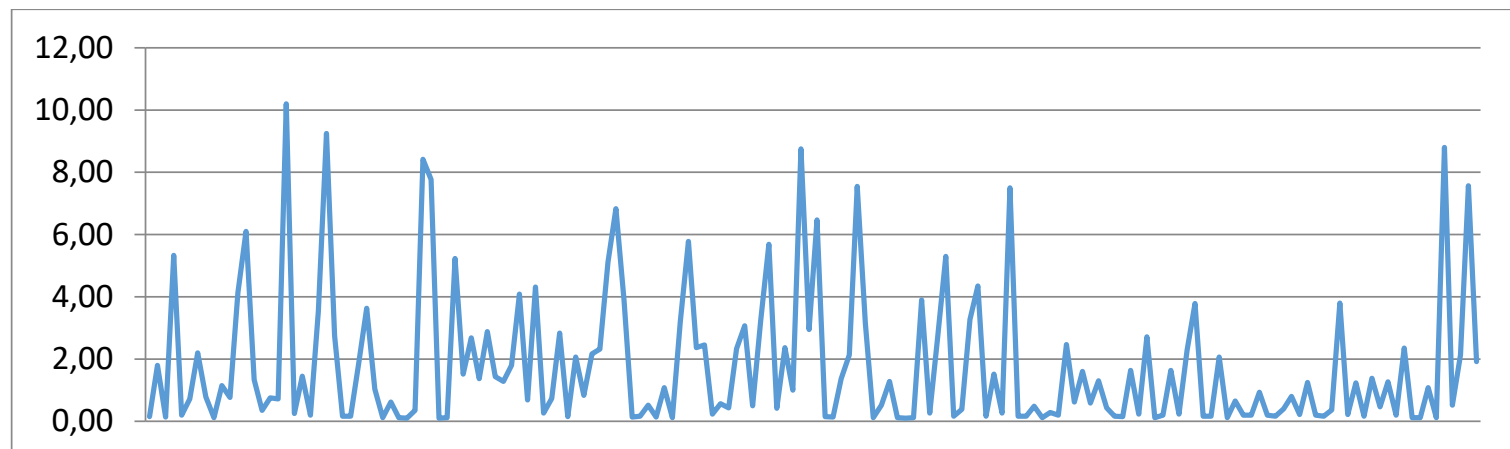

Figure 5: Customer arrival time in minutes on August 13, 2018.

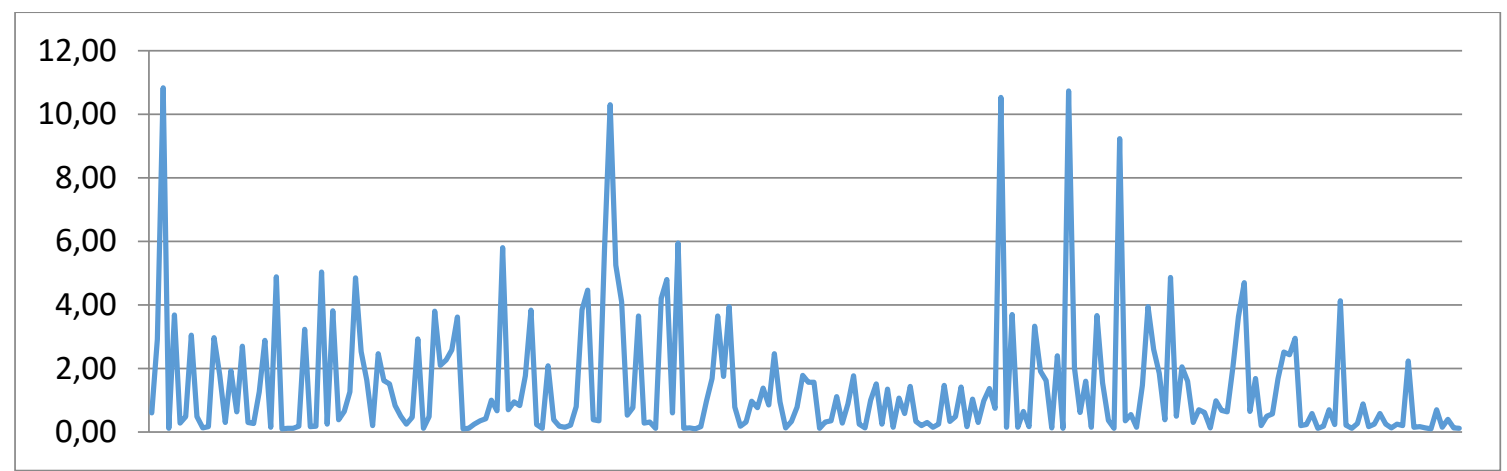

Figure 6: Customer arrival time in minutes on August 14, 2018. 
INDEPENDENT JOURNAL OF MANAGEMENT \& PRODUCTION (IJM\&P)

http://www.ijmp.jor.br

v. 11, n. 3, May-June 2020

ISSN: 2236-269X

DOI: 10.14807/ijmp.v11i3.1074

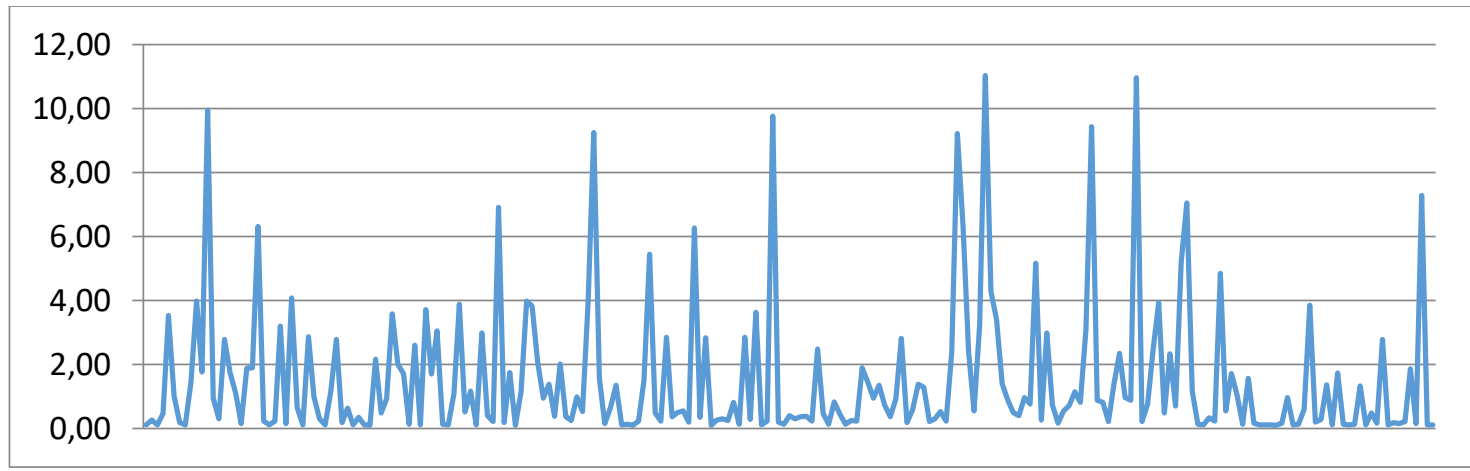

Figure 7: Customer arrival time in minutes on August 18, 2018.

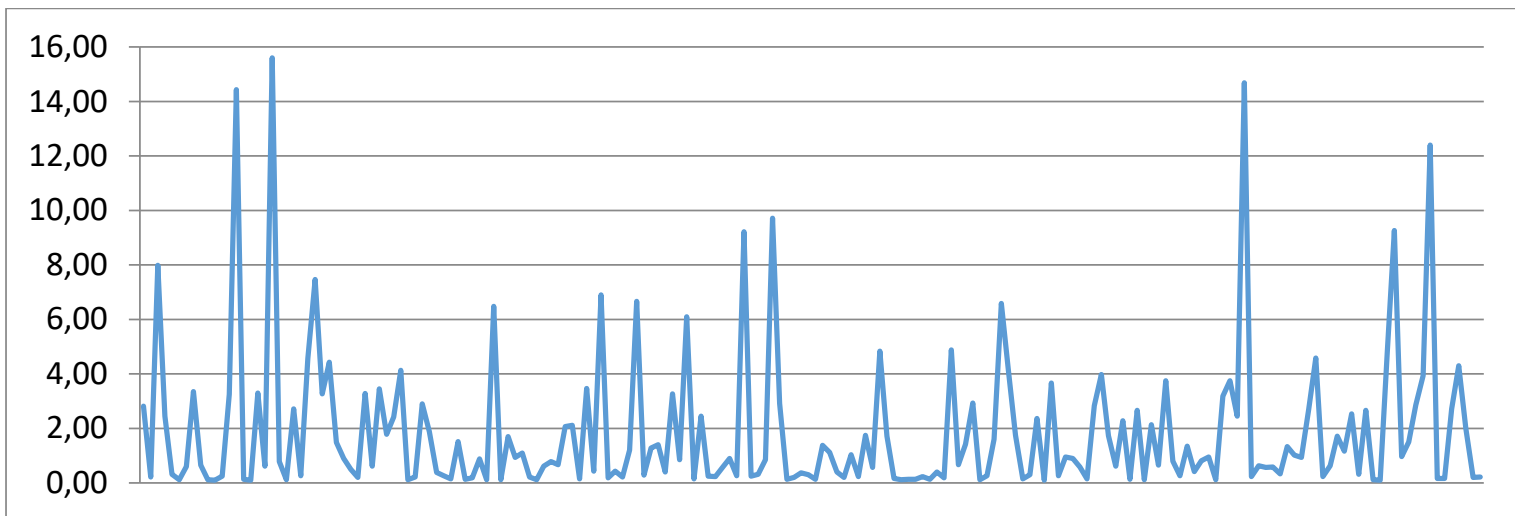

Figure 8: Customer arrival time in minutes on August 19, 2018.

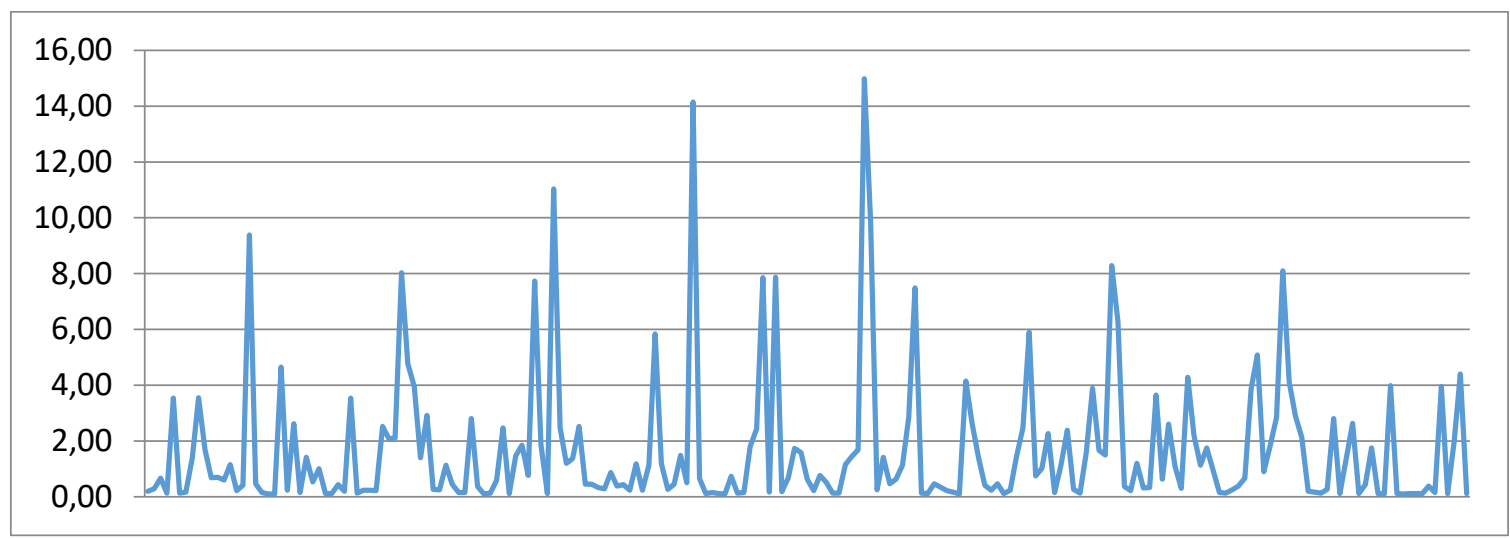

Figure 9: Customer arrival time in minutes on August 20, 2018.

These data were processed by the Input Analyzer software, complementary to Arena ${ }^{\circledR} 12$, to determine the best probability distribution that adheres to the set of values. In the same way, it was carried out with the data referring to the time of service of the conventional boxes, according to the attendants during working hours, fragmented in periods of 1 hour. The F2 element in Table 3 shows the theoretical distributions of probabilities that best adhere to the stochastic behavior of the variables for each 1-hour interval of the agency's operation. 
ISSN: 2236-269X

DOI: 10.14807/ijmp.v11i3.1074

After data collection and identification of the behavior of the variables that represent the customer flow dynamics in the bank branch, the conceptual model of the system was shown, shown in Figure 10.

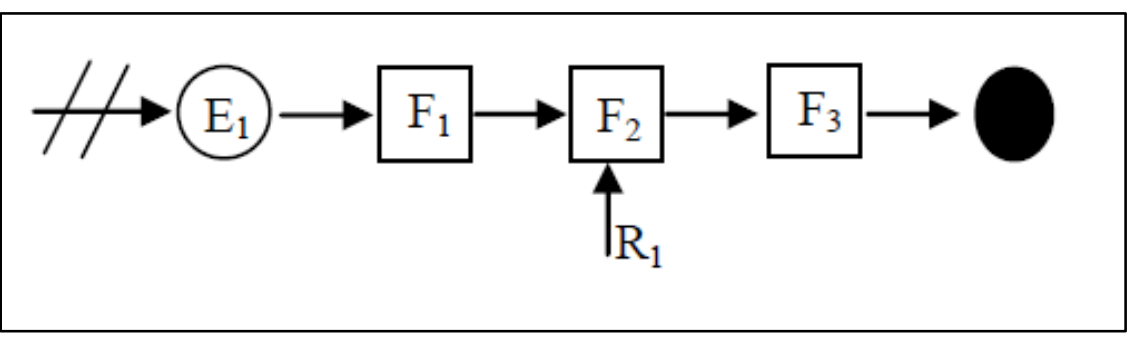

Figure 10: Conceptual model of customer flow in the bank branch.

Table 3: Description and parameters of the elements of the conceptual model.

\begin{tabular}{|c|c|c|}
\hline \multicolumn{2}{|r|}{ Description } & Parameters \\
\hline \multirow{5}{*}{ E1 } & \multirow{5}{*}{$\begin{array}{l}\text { Arrival of customers for conventional } \\
\text { service }\end{array}$} & $\begin{array}{l}\text { Weibull (average: } 1.46 \text { e deviation: } 0.747 \text { ) min - 11:00 a.m. - } \\
\text { 12:00 p.m. }\end{array}$ \\
\hline & & $\begin{array}{l}12 * \text { Beta (average: } 0.539 \text { e deviation 3.19) min - 12:00 p.m. - } \\
\text { 13:00 p.m. }\end{array}$ \\
\hline & & $\begin{array}{l}15 * \text { Beta (average: } 0.335 \text { e deviation: } 2.44 \text { ) min - 13:00 p.m. } \\
\text { - 14:00 p.m. }\end{array}$ \\
\hline & & $\begin{array}{l}\text { Weibull (average: } 1.44 \text { e deviation: } 0.814 \text { ) } \min \text { - 14:00 p.m.- } \\
\text { 15:00 p.m. }\end{array}$ \\
\hline & & $\begin{array}{l}\text { Lognormal (average: } 1.71 \text { e deviation: } 3.19 \text { ) min - 15:00 p.m.- } \\
\text { 16:00 p.m. }\end{array}$ \\
\hline F1 & $\begin{array}{l}\text { Location for conventional service } \\
\text { queue }\end{array}$ & Infinite capacity \\
\hline \multirow{5}{*}{ F2 } & \multirow{5}{*}{ Conventional service } & $\begin{array}{l}\text {-0.001 + Exponential (average: } 3.67 \text { ) min - 11:00 a.m. - 12:00 } \\
\text { p.m. }\end{array}$ \\
\hline & & $\begin{array}{l}\text {-0.001 + Exponential (average: } 3.37 \text { ) min - 12:00 p.m. - 13:00 } \\
\text { p.m. }\end{array}$ \\
\hline & & $\begin{array}{l}15 * \text { Beta (average: } 0.62 \text { e deviation: } 2.85 \text { ) min - 13:00 p.m. - } \\
\text { 14:00 p.m. }\end{array}$ \\
\hline & & $\begin{array}{l}\text { Gama (average: } 4.41 \text { e deviation: } 0.614 \text { ) } \min \text { - 14:00 p.m. - } \\
\text { 15:00 p.m. }\end{array}$ \\
\hline & & $\begin{array}{l}\text {-0.001 + Exponential (average: } 2.98 \text { ) min - 15:00 p.m. - 16:00 } \\
\text { p.m. }\end{array}$ \\
\hline F3 & Location to exit & Infinite capacity \\
\hline R1 & Conventional service & 4 service desks \\
\hline
\end{tabular}

Regarding the number of employees working in the offices during the period of operation of the agency, it was decided to insert these conditions in the computational model through the Schedule resource. This resource establishes capacity rules that will be effective in certain periods of time. 
ISSN: 2236-269X

DOI: 10.14807/ijmp.v11i3.1074

\section{ANALYSIS OF RESULTS}

\subsection{Current agency banking scenario}

As is known, this study aimed at achieving the objectives outlined at the beginning of work, seeks to quantify and analyze, in a bank of the southern state of Rio de Janeiro, the following variables: number of customers in the queue, queue waiting time, service time and the percentage of occupancy of banking service desks (Table 4 and Table 5). Table 5 shows the customer time in the system (lead time), in other words, the time the customer spent in the queue plus the service time performed by the conventional service.

The results to be presented below are, in fact, mean values obtained from all replications in each time period. The number of replications was 22, referring to the number of business days in a month of operation of the agency banking.

Table 4: Results regarding the current agency banking scenario.

\begin{tabular}{|c|c|c|c|c|c|c|}
\hline \multicolumn{7}{|c|}{ Current agency banking scenario } \\
\hline & \multicolumn{2}{|c|}{$\begin{array}{l}\text { Number of customers } \\
\text { in the queue }\end{array}$} & \multicolumn{2}{|c|}{ Queue waiting time (min.) } & \multicolumn{2}{|c|}{$\begin{array}{c}\text { Occupancy rate of banking } \\
\text { service }\end{array}$} \\
\hline & Average & Maximum & Average & Maximum & Average & Maximum \\
\hline $\begin{array}{l}\text { 11:00 a.m. - } \\
\text { 12:00 p.m. }\end{array}$ & 0.3264 & 1.3997 & 2.8576 & 12.2899 & \multirow{6}{*}{$50.07 \%$} & \multirow{6}{*}{$60.78 \%$} \\
\hline $\begin{array}{l}\text { 12:00 p.m. } \\
\text { 01:00 p.m. }\end{array}$ & 0.1875 & 0.7497 & 1.8244 & 7.2452 & & \\
\hline $\begin{array}{l}\text { 01:00 p.m. - } \\
\text { 02:00 p.m. }\end{array}$ & 0.1025 & 0.4612 & 1.0465 & 4.3692 & & \\
\hline $\begin{array}{l}\text { 02:00 p.m. - } \\
\text { 03:00 p.m. }\end{array}$ & 0.1069 & 0.5764 & 0.9170 & 4.3229 & & \\
\hline $\begin{array}{l}\text { 03:00 p.m. - } \\
\text { 04:00 p.m. }\end{array}$ & 0.0836 & 0.6745 & 0.6873 & 4.8564 & & \\
\hline Average & 0.1614 & 0.7723 & 1.4666 & 6.6167 & & \\
\hline
\end{tabular}

Table 5: Results of waiting time and service time of the current agency banking scenario.

\begin{tabular}{c|c|c|c|c}
\hline \multicolumn{4}{c}{ Current agency banking scenario } \\
\cline { 2 - 4 } & \multicolumn{2}{|c|}{ Waiting time (min.) } & \multicolumn{2}{c}{ Service time (min) } \\
\cline { 2 - 4 } & Average & Maximum & Average & Maximum \\
\hline 11:00 a.m. - 12:00 p.m. & 7.1465 & 40.4608 & 4.2889 & 28.1709 \\
\hline 12:00 p.m. 01:00 p.m. & 5.9155 & 32.6180 & 4.0911 & 25.3728 \\
\hline 01:00 p.m. - 02:00 p.m. & 4.6425 & 37.8214 & 3.5960 & 33.4522 \\
\hline 02:00 p.m. - 03:00 p.m. & 3.7207 & 32.9380 & 2.8037 & 28.6151 \\
\hline 03:00 p.m. - 04:00 p.m. & 3.6276 & 20.8917 & 2.9403 & 16.0353 \\
\hline Average & $\mathbf{5 . 0 1 0 6}$ & $\mathbf{3 2 . 9 4 6 0}$ & $\mathbf{3 . 5 4 4 0}$ & $\mathbf{2 6 . 3 2 9 3}$ \\
\hline
\end{tabular}

The results revealed that the agency showed great performance and waiting time and number of customers in the queue. However, it showed a relatively low rate of occupancy of the banking service desks, that is, there was a significant percentage in which the banking service desks became idle. 
INDEPENDENT JOURNAL OF MANAGEMENT \& PRODUCTION (IJM\&P)

http://www.ijmp.jor.br

v. 11, n. 3, May-June 2020

ISSN: 2236-269X

DOI: 10.14807/ijmp.v11i3.1074

\subsection{New agency banking scenario}

Based on the results obtained, a new scenario was designed in order to allow a different situation to be assessed in relation to the flow of clients that the agency may be subject to. This scenario is described below and considers the number of attendants (banking service desks) working during the working period.

The results of the simulations of the respective scenarios are presented in Tables 6 and 7. The comparative results are shown in Table 8.

It was simulated to decrease the number of conventional executive service from 3 (three) to 2 (two) banking service desks during the first 3 (three) hours of operation of the agency banking and from 4 (four) to 3 (three) banking service desks in the last hour of working.

Table 6: Results regarding the new agency banking scenario.

\begin{tabular}{|c|c|c|c|c|c|c|}
\hline \multicolumn{7}{|c|}{ New agency banking scenario } \\
\hline & \multicolumn{2}{|c|}{$\begin{array}{c}\text { Number of customers in the } \\
\text { queue }\end{array}$} & \multicolumn{2}{|c|}{$\begin{array}{c}\text { Queue waiting time } \\
\text { (min.) }\end{array}$} & \multicolumn{2}{|c|}{$\begin{array}{c}\text { Occupancy rate of } \\
\text { banking service }\end{array}$} \\
\hline & Average & Maximum & Average & Maximum & Average & Maximum \\
\hline $\begin{array}{l}\text { 11:00 a.m. - } 12: 00 \\
\text { p.m. }\end{array}$ & 0.9480 & 3.6402 & 8.5486 & 30.4762 & \multirow{6}{*}{$71.10 \%$} & \multirow{6}{*}{$93.82 \%$} \\
\hline $\begin{array}{l}\text { 12:00 p.m. 01:00 } \\
\text { p.m. }\end{array}$ & 1.2872 & 4.0501 & 12.3475 & 37.3852 & & \\
\hline $\begin{array}{l}\text { 01:00 p.m. - 02:00 } \\
\text { p.m. }\end{array}$ & 0.9577 & 4.5105 & 9.1531 & 36.9042 & & \\
\hline $\begin{array}{l}\text { 02:00 p.m. - 03:00 } \\
\text { p.m. }\end{array}$ & 0.7563 & 3.1126 & 6.7289 & 20.0097 & & \\
\hline $\begin{array}{c}\text { 03:00 p.m. - 04:00 } \\
\text { p.m. }\end{array}$ & 0.5350 & 3.1387 & 4.3665 & 20.5444 & & \\
\hline Average & 0.8968 & 3.6904 & 8.2289 & 29.0639 & & \\
\hline
\end{tabular}

Table 7: Results of waiting time and service time of the new agency banking scenario.

\begin{tabular}{c|c|c|c|c}
\hline & \multicolumn{3}{|c}{ Wew agency banking scenario } & \multicolumn{2}{c}{ Service time (min) } \\
\cline { 2 - 4 } & Average & Maximum & Average & Maximum \\
\hline 11:00 a.m. - 12:00 p.m. & 13.6301 & 55.3530 & 5.0815 & 24.8768 \\
\hline 12:00 p.m. 01:00 p.m. & 16.1369 & 70.7904 & 3.7894 & 33.4052 \\
\hline 01:00 p.m. - 02:00 p.m. & 13.3224 & 72.0594 & 4.1693 & 35.1552 \\
\hline 02:00 p.m. - 03:00 p.m. & 9.8860 & 45.1307 & 3.1571 & 25.1210 \\
\hline 03:00 p.m. - 04:00 p.m. & 7.6390 & 49.2781 & 3.2725 & 28.7337 \\
\hline Average & $\mathbf{1 2 . 1 2 2 9}$ & $\mathbf{5 8 . 5 2 2 3}$ & $\mathbf{3 . 8 9 4 0}$ & $\mathbf{2 9 . 4 5 8 4}$ \\
\hline
\end{tabular}

Table 8: Comparison between the results of the current scenario and the new simulated scenario.

\begin{tabular}{l|c|c}
\hline & Current scenario & New scenario \\
\hline Average number of customers in the queue & 0,1614 & 0,8968 \\
\hline Average waiting time in queue (min.) & 1,4666 & 8,2289 \\
\hline Average service time (min.) & 3,5440 & 3,8940 \\
\hline Average system waiting time (min.) & 5,0106 & 12,1229 \\
\hline Average occupancy rate & $50,07 \%$ & $71,10 \%$ \\
\hline
\end{tabular}


ISSN: 2236-269X

DOI: 10.14807/ijmp.v11i3.1074

\section{CONCLUSION}

The model adequately described the behavior of the system under study and proved to be an important tool to assist banking managers in making decisions about the operation of the resources and to better control the behavior of the queues.

By means of the obtained results, that the number of people in the queue in the current system studied is not significant, being approximately, on average, 0.1614 people, which makes a change to a larger number of attendants unnecessary.

Due to the absence of significant queues, the proposal for a reduction in the number of attendants appeared. It was observed that the queue that would be formed, with two attendants (and three in the last hour of operation), would remain relatively small, with 0.8968 people waiting an average time of 8.22289 minutes to be attended, average of 1.4666 minutes from the previous scenario.

In addition, it was noticed that the average occupancy rate of these attendants would be higher when compared to the current situation of the bank agency, that is, the employees would be $71.10 \%$ occupied during the interval of operation. In the previous scenario, a low rate of employee occupancy (50.07\%).

The model was consistent with the real system, clearly showing that during the time period analyzed in the bank agency, it does not have large queues and people wait a short time to be answered, which could be confirmed with the data provided by the banking service management.

In view of this, remaining in the proposed situation with three attendants in total (two counters operating in the first four hours and three counters in the last hour) is the best alternative, since there are no significant queues for this situation and the employees are not overburdened, or the occupancy rate may be considered acceptable although higher than the previous scenario.

It is also worth mentioning the application of IDEF-SIM in conceptual modeling. As indicated in the paper by Leal, Almeida and Montevechi (2008), the creation of the conceptual model, using appropriate syntax and semantics, gives more agility to the translation process of the computational model, improving the development of the simulation project as a whole. 
DOI: 10.14807/ijmp.v11i3.1074

\section{REFERENCES}

ANDRADE, E. L. (2009) Problemas de Congestionamento das Filas. Introdução à Pesquisa Operacional: Métodos e modelos para análise de decisões, 4 ed. Rio de Janeiro: LTC.

ARENALeS, M. et al. (2007) Pesquisa operacional, 1 ed. Rio de Janeiro: Elsevier.

BOUZADA, M. A. C. (2009) Dimensionamento de um call center: simulação ou Teoria das Filas?, In: SIMPÓSIO DE ADMINISTRAÇÃO DA PRODUÇÃO, 12, São Paulo, Proceedings... São Paulo: SIMPOI, 2009.

CAMARGO, P. O. (2009) A evolução recente do setor bancário no Brasil. São Paulo: Editora UNESP.

CAMELO, G. R.; COELHO, A. S.; BORGES, R. M.; SOUZA, R. M. (2010) Teoria da filas e da simulação aplicada ao embarque de minério de ferro manganês no terminal marítimo de ponta da madeira. Instituto Militar de Engenharia. Rio de Janeiro: Cadernos do IME - Serie estatística.

CHWIF, L.; MEDINA, A. (2006) Modelagem e Simulação de Eventos Discretos: Teoria \& Aplicações. São Paulo: Editora dos Autores.

DOILE, L. F. P. (2010) Teoria de filas: analisando o fluxo de atendimento e o número de atendimento em um supermercado. Monography. Porto Alegre: UFRGS. Available: https://lume.ufrgs.br/handle/10183/29741. Access: 15/02/2018.

FERNANDES, D. V. H.; SANTOS, C. P. (2008) As conseqüências comportamentais da insatisfação dos clientes. Revista de Administração Contemporânea, v. 12, p. 147-174.

FIEBIG, É. A.; FREITAS, E. C. (2011) Canais de atendimento, satisfação e lucratividade de clientes em serviços: um caso bancário. Revista Eletrônica de Administração, v. 17, n. 3, p. 742-775.

FOGLiATTI, M. C.; MATTOS, N. M. C. (2007) Teoria de filas. Rio de Janeiro: Interciência.

FREITAS FILHO, P. J. (2008) Introdução à Modelagem e Simulação de Sistemas com Aplicações em ARENA ${ }^{\circledR}, 2$ ed. Florianopolis: Visual Books.

GUEDES, D. B.; ARAÚJO, A. C. (2013) Gestão de filas: um estudo de caso em torno da qualidade dos serviços numa agência bancária da região metropolitana do Recife - PE. In: ENCONTRO NACIONAL DE ENGENHARIA DE PRODUÇÃO, 23, Salvador, Proceedings... Salvador: ENEGEP, 2013.

HILLIER, F. S.; LIEBERMAN, G. J. (2013) Introdução à pesquisa operacional, 9 ed. Porto Alegre: AMGH.

JUNIOR, F. C. (2017) Teoria das filas como uma ferramenta auxiliar do Just In Time. In: ENCONTRO NACIONAL DE ENGENHARIA DE PRODUÇÃO, 27, Joinville, Proceedings... Joinville: ENEGEP, 2017.

KELTON, W. D.; SADOWSKI, R. P.; STURROCK, D. T. (2007) Simulation with Arena, 4 ed. New York: McGraw- Hill.

LABADESSA, L. S.; OLIVEIRA, L. J. (2012) A importância da qualidade no atendimento ao cliente um estudo bibliográfico. Revista FIAR, p. 1-14.

LEAL, F.; ALMEIDA, D. A.; MONTEVECHI, J. A. B. (2008) Uma Proposta de Técnica de Modelagem Conceitual para a Simulação através de Elementos do IDEF. In: SIMPÓSIO 
BRASILEIRO DE PESQUISA OPERACIONAL, 51, João Pessoa, Proceedings... João Pessoa: SBPO, 2008.

LOVELOCK, C.; WIRTZ. J. (2006) Marketing de serviços - Pessoa, tecnologia e resultados, 5 ed. São Paulo: Pearson.

MARINS, F. A. S. (2011) Introdução à Pesquisa Operacional. São Paulo: Cultura Acadêmica, Pró-Reitoria de Graduação da UNESP.

MARQUES, C. F. (2012) Estratégia de gestão da produção e operações. Curitiba: IESDE Brasil.

MARTINS, H. S. et al. (2017) Aplicação da teoria das filas para avaliação de desempenho de uma agencia dos correios de Abaetetuba. In: ENCONTRO NACIONAL DE ENGENHARIA DE PRODUÇÃO, 27, Joinville, Proceedings... Joinville: ENEGEP, 2017.

MOREIRA, D. A. (2007) Pesquisa Operacional: curso introdutório, 2 ed. São Paulo: Thomson Learning.

NUNES, R. G.; NOGUEIRA, R. T. (2013) Simulação de uma Agência Bancária para fins de Avaliação de Indicadores de Desempenho. In: CONGRESSO FLUMINENSE DE INICIAÇÃO CIENTÍFICA E TECNOLÓGICA, 5, Campos dos Goytacazes, Proceedings... Campos dos Goytacazes: CONFICT, 2013.

PINTO, A. S. (2011) Aplicação da teoria de filas na análise da capacidade operacional de um sistema - estudo caso BCA Porto Novo. Cabo Verde: Instituto Superior de Ciências Ecnômicas e Empresariais.

PRADO, D. (1999) Usando o ARENA® em Simulação, 2 ed. Belo Horizonte: Editora de Desenvolvimento Gerencial.

PRADO, D. (2009) Teoria das filas e da simulação, 4 ed. Nova Lima: INDG Tecnologia e Serviços Ltda.

SANTOS, C. M. S.; LIRA, L. M. L. (2017) Avaliação do atendimento em unidades de pronto atendimento estudo de caso aplicado teoria das filas. In: ENCONTRO NACIONAL DE ENGENHARIA DE PRODUÇÃO, 27, Joinville, Proceedings... Joinville: ENEGEP, 2017.

SCHEMENNER, R. W. (1999).Administração de operações em serviços. São Paulo: Futura. VERGARA, S. C. (2016).Projetos e relatórios de pesquisa em administração, 16 ed. São Paulo: Atlas.

ZACHARIAS, M. L. B.; FIGUEIREDO, K. F.; ALMEIDA, V. M. C. (2008).Determinantes da satisfação dos clientes com serviços bancários. Revista Eletrônica de Administração, v. 7, n. 2, p. 1-23.

ZENOTE, L. C. (2007).Gestão do Relacionamento com o Cliente e a Competitividade Empresarial. São Paulo: Novatec Editora. 